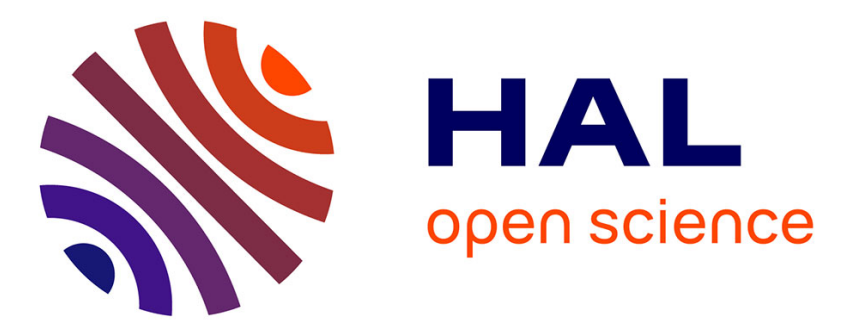

\title{
Prognostics and Health Management of PEMFC - state of the art and remaining challenges.
}

Marine Jouin, Rafael Gouriveau, Daniel Hissel, Marie-Cécile Péra, Noureddine Zerhouni

\section{- To cite this version:}

Marine Jouin, Rafael Gouriveau, Daniel Hissel, Marie-Cécile Péra, Noureddine Zerhouni. Prognostics and Health Management of PEMFC - state of the art and remaining challenges.. International Journal of Hydrogen Energy, 2013, 38, pp.15307-15317. 10.1016/j.ijhydene.2013.09.051 . hal-00872866

\section{HAL Id: hal-00872866 https://hal.science/hal-00872866}

Submitted on 14 Oct 2013

HAL is a multi-disciplinary open access archive for the deposit and dissemination of scientific research documents, whether they are published or not. The documents may come from teaching and research institutions in France or abroad, or from public or private research centers.
L'archive ouverte pluridisciplinaire HAL, est destinée au dépôt et à la diffusion de documents scientifiques de niveau recherche, publiés ou non, émanant des établissements d'enseignement et de recherche français ou étrangers, des laboratoires publics ou privés. 


\title{
Prognostics and Health Management of PEMFC - state of the art and remaining challenges
}

\author{
Marine Jouin*, Rafael Gouriveau, Daniel Hissel, Marie-Cécile Péra, Noureddine Zerhouni \\ FEMTO-ST Institute, UMR CNRS 6174 - UFC / ENSMM / UTBM, \\ FC-LAB Research, FR CNRS 3539, \\ 24 rue Alain Savary, 25000 Besançon, France \\ firstname.lastname@femto-st.fr
}

\begin{abstract}
Fuel Cell systems (FC) represent a promising alternative energy source. However, even if this technology is close to being competitive, it is not ready for large scale industrial deployment: FC still must be optimized, particularly by increasing their limited lifespan. This involves a better understanding of wearing processes and requires emulating the behavior of the whole system. Furthermore, a new area of science and technology emerges: Prognostics and Health Management (PHM) appears to be of great interest to face the problems of health assessment and life prediction of FCs. According to this, the aim of this paper is to present the current state of the art on PHM of FCs, more precisely of Proton-Exchange Membrane Fuel Cells (PEMFC) stack. PHM discipline is described in order to depict the processing layers that allow early deviations detection, avoiding faults, deciding mitigation actions, and thereby increasing the useful life of FCs. On this basis, a taxonomy of existing works on PHM of PEMFC is given, highlighting open problems to be addressed. The whole enables getting a better understanding of remaining challenging issues in this area.
\end{abstract}

Keywords: Proton exchange membrane (PEM) fuel cell, PHM, Prognostics, Health Management, Issues, Challenges

\section{Introduction}

In the quest for the best candidate to replace fossil energy, fuel cell systems benefit from a growing interest. Not only, are they presented as a good alternative to internal combustion engine in transport applications, but also as a clean and efficient portable power source for low power electronic devices $(\mu \mathrm{FC})$ or, on a bigger scale, for combined heat and power systems $(\mu \mathrm{CHP})$ that are used to generate both heat and electricity for homes. As a fuel cell has no moving part, it offers a great reliability even if subjected to material degradation. However, it still suffers from a too short life duration which impedes large scale deployment of this technology.

For its part Prognostics and Health Management can be seen as a great option to help research on extending PEMFC lifetime. Indeed, it appears to be an enabling discipline that aims at utilizing real monitoring data to facilitate relevant indicators and trends that depict the health of the system [1]. Also, Prognostics and Health Management discipline enables deciding adequate actions at the right time when needed in order to extend the system's life, and it benefits from a growing interest from FC community. Nevertheless, no work dealing with Prognostics and Health Management applied to fuel cells can

*Corresponding author, Tel.: +33 (0)3 814029 04, Fax +33 (0)3 81402809 be found in literature. Consequently, this paper aims at drawing a first classification of PEMFC works with Prognostics and Health Management point of view. From that, current and future challenging issues are pointed out.

To achieve this goal, the core of the paper is organized in three main sections. First, Prognostics and Health Management discipline is briefly described with an emphasis on prognostics. This part enables distinguishing important sets of activities to be carried out and setting the specific vocabulary used all along the paper. Then, main degradation and behavioral models of PEMFC are synthesized in order to depict the variety of aspects to be taken into account for Prognostics and Health Management purpose. All these bases set, the state of the art is drawn according to the processing layers defined sooner. This enables discussing in a last part remaining challenging issues.

\section{Prognostics and Health Management (PHM)}

\subsection{Outline : processing layers of PHM}

The growth of reliability, availability or safety demand is a determining factor to ensure all new industrial systems spreading. Maintenance has been introduced as an efficient way to meet these requirements while reducing cost of the useful life of the system. Current maintenance strategies have moved from breakdown maintenance, to 
preventive maintenance, then to Condition-Based Maintenance $(\mathrm{CBM})$. The objective of $\mathrm{CBM}$ is to maintain the correct equipment at the correct time taking into account the current and future health state of the system. CBM is based on using real-time monitoring data to estimate the actual health state of the system and thereby optimize maintenance policies. Consequently, the complete aspects of failure analysis and prediction must be viewed as a set of activities, all of them must be performed. Indeed, various activities, ranging from data collection through the recommendation of specific mitigation actions, must be carried out to perform predictive control and maintenance (and thereby improve systems' performances). Prognostics and Health Management follows from that. It can be defined as a set of activities which main perspective is to enhance the effective reliability and availability of a product in its life-cycle conditions by detection of current and approaching failures. It aims at predicting and protecting the integrity of equipment and complex systems, and at avoiding unanticipated operational problems leading to mission performance deficiencies, degradation, and adverse effects to mission safety. To achieve this goal, a PHM system is seen as the integration of seven layers (initially defined for CBM). A general PHM architecture is proposed on Fig. 1. A description of each layer is given hereafter.

- Layer 1: Data Acquisition

It provides the PHM application with digitized sensor or transducer data.

- Layer 2: Data Processing

It receives data from the sensors (or transducers or signal processors), and performs signal transformations and features extraction, reduction and selection.

- Layer 3: Condition Assessment

It helps determining the system current state-ofhealth by detecting and localizing a system fault. It compares on-line data with expected values of system's parameters. It should also be able to generate alerts based on preset operational limits.

- Layer 4: Diagnostic

It determines if the condition of the system has degraded. The module also generates a diagnostic record and suggests fault possibilities. It permits to isolate and to identify the component that has ceased to operate (past propagation: from effects to causes).

\section{- Layer 5: Prognostics}

It predicts the future condition of the monitored system, subsystem or component. The module should be able to acquire data from all previous modules (propagation from causes to effects).

\section{- Layer 6: Decision Support}

Its primary function is to provide recommended maintenance actions or alternatives on how to run the sys- tem until the mission is completed. It should be done automatically.

- Layer 7: Human-Machine Interface (HMI)

This module receives data from all previous modules. This module could be built into a regular humanmachine interface.

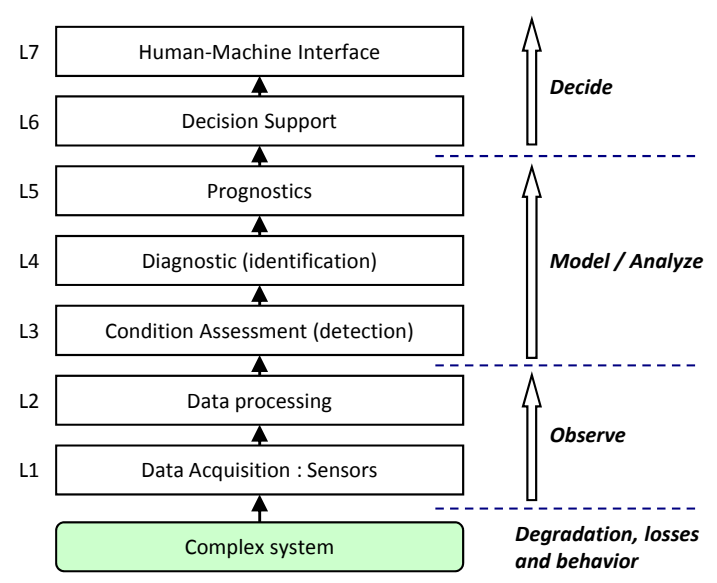

Figure 1: PHM Architecture adapted from [2]

From this description, one can guess the great interest of prognostics. Let's now focus on this layer.

\subsection{Prognostics: a Key Process}

Global performance requirements lead industrials to strengthen their capability to anticipate degradation phenomena and failures. This is mainly achieved thanks to prognostics, that appears to be a key process to move from a "fail to fix" to a "predict to prevent" strategy (Fig. 2), enabling the improvement of reliability, availability and safety of systems, while reducing costs and down times.

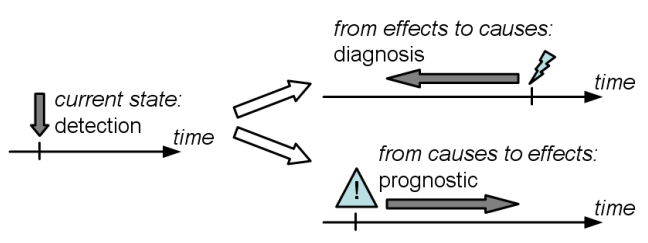

Figure 2: Anticipating instead of fixing [3]

Although there are some divergences in literature, prognostics can be defined as proposed by the International Organization for Standardization: "prognostics" is the estimation of time to failure and risk for one or more existing and future failure modes [4]. In this acceptation, prognostics is also called the "prediction of a system's lifetime" as it is a process whose objective is to predict the Remaining Useful Life (RUL) before a failure occurs, given the current machine condition and its past operation profile 
(Fig. 3). Various approach exist to perform prognostics, and it does not exist a unique classification. Great reviews of these methods can be seen in $[5,6,7,8]$.

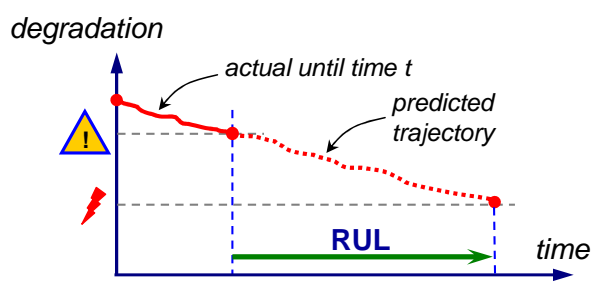

Figure 3: RUL illustration

\subsection{Towards PHM of PEMFC}

Over the past 20 years, many successful applications and implementations of PHM theory in industrial problems have been presented in the literature, that for very different kinds of systems such as mechanical systems [9, 10], machining tools [11], air cooling systems [12] or electrochemical devices [13]. Hundreds of papers in PHM (both theoretical and applied) appear every year in academic journals, conference proceedings and technical reports. This makes PHM a very interesting tool for monitoring the state-of-health ( $\mathrm{SOH})$ and estimating the remaining useful life (RUL) of PEMFC with the aim of extending its durability. In the sections below, we propose to discuss PHM of PEMFC by considering main sets of aspects depicted in Fig. 1: "degradation, losses and behavior" (section 3), "observation", "modeling / analysis" and "decision" (section 4).

\section{Degradation and behavior of PEM Fuel Cells}

\subsection{Degradation mechanisms}

Due to its components and all the ancillaries surrounding, PEMFC implies several scales as depicted in Fig. 4 adapted from [14] but also multi physics phenomena, namely electrical, mechanical, electrochemical and thermodynamic phenomena. Consequently, a great number of parameters influencing performances, degradation and durability of PEMFC can be identified. They can be attributed to operating conditions, cell design and assembly, environmental conditions and degradation mechanisms.

Great reviews of the main parameters have been done in $[15,16,17,18,19]$, they are relative to various fields: water management (flooding or drying out of the membrane - electrode assembly), components degradation (see Table 1), contamination (CO poisoning, presence of impurities initiating chemical attacks), reactant gas starvation or thermal management (influence of freezing or elevated temperature). These parameters, if not properly monitored and controlled, can lead to irreversible degradations

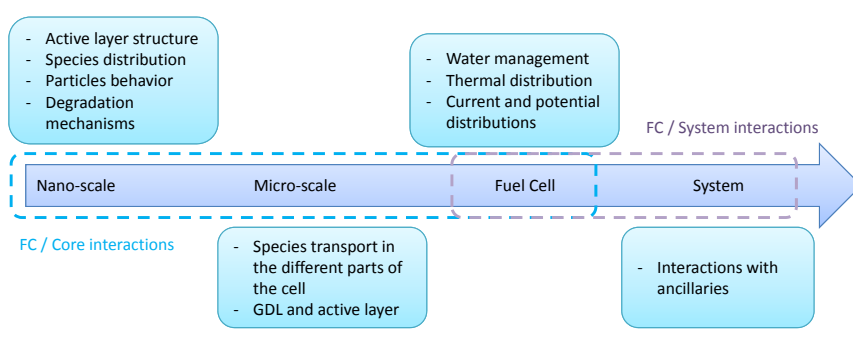

Figure 4: PEMFC: a multi scales system adapted from [14]

and thus to the PEMFC failure.

Obviously, performance degradation cannot be avoided in a long-term period, but mitigation strategies can be used to prevent their consequences [19]. However it implies that all the phenomena previously listed are completely understood.

\subsection{Behavior and losses through the lifetime}

\subsubsection{Behavioral models}

As we said, PEMFCs are multiphysics systems, which make highly difficult the establishment of a complete behavioral model. Furthermore such a model would hardly be exploitable for practical applications due to the number of parameters and the impossibility of monitoring some of them. But before elaborating a complex model, one has to think carefully of the purpose of its model. Indeed, not the same models are requested when a diagnosis is performed, when the system command is investigated or when the purpose is developing the system. Considering that, the level of the model has to be chosen (microscopic or macroscopic): dimension 0 can be enough for an elementary cell study whereas three dimensions are needed to take into account phenomena like mass transport or electrochemical interactions.

Different types of models are already used for PEMFCs studies: static / dynamic models, analytical models (physical or mathematical), hybrid approaches (physical and empirical models associated) [20], black-box models (data driven approaches such as neural networks [21], fuzzy inference systems [22], support vector machines [23], etc.). As for an example, a common model for an electrical approach of PEMFC is the adaptation of the Randles model proposed by [24], or the equivalent circuit model proposed by [25]. Reviews of modeling of PEMFC can be found in $[26,27,28,29]$.

\subsubsection{Losses in PEMFC}

Another efficient way to study PEMFC is to characterize them, namely with polarization curves and Nyquist plots. These characterizations allow catching the static and dynamic behaviors of the stack and the curves give useful information regarding losses and internal resistances in the system. If we take a closer look at the polarization curve 
Table 1: Components degradation in the stack [19]

\begin{tabular}{|c|c|c|}
\hline Component & Failure modes & Causes \\
\hline Membrane & $\begin{array}{l}\text { Mechanical degradation } \\
\text { Thermal degradation } \\
\text { Chemical/electrochemical degradation }\end{array}$ & $\begin{array}{l}\text { Mechanical stress due to non-uniform press pressure, inade- } \\
\text { quate humidification or penetration of the catalyst and seal } \\
\text { material traces } \\
\text { Thermal stress; thermal cycles } \\
\text { Contamination; radical attack }\end{array}$ \\
\hline Catalyst layer & $\begin{array}{l}\text { Loss of activation } \\
\text { Conductivity loss } \\
\text { Decrease in mass transport rate of reactants } \\
\text { Loss of reformate tolerance } \\
\text { Decrease in water management ability }\end{array}$ & $\begin{array}{l}\text { Sintering or dealloying of electrocatalyst } \\
\text { Corrosion of electrocatalyst support } \\
\text { Mechanical stress } \\
\text { Contamination } \\
\text { Change in hydrophobicity of materials due to Nafion or } \\
\text { PTFE dissolution }\end{array}$ \\
\hline GDL & $\begin{array}{l}\text { Decrease in mass transport } \\
\text { Decrease in water management ability } \\
\text { Conductivity loss }\end{array}$ & $\begin{array}{l}\text { Degradation of backing material } \\
\text { Mechanical stress; change in the hydrophobicity of materials } \\
\text { Corrosion }\end{array}$ \\
\hline Bipolar plates & $\begin{array}{l}\text { Conductivity loss } \\
\text { Fracture/deformation }\end{array}$ & $\begin{array}{l}\text { Corrosion; oxidation } \\
\text { Mechanical stress }\end{array}$ \\
\hline Sealing gasket & Mechanical failure & Corrosion; mechanical stress \\
\hline
\end{tabular}

on Fig. 5 for example, we can distinguish four zones corresponding to addition of different types of losses. The Nyquist plot, as for it, can be used to study the behavior evolution during aging process $[30,31]$.

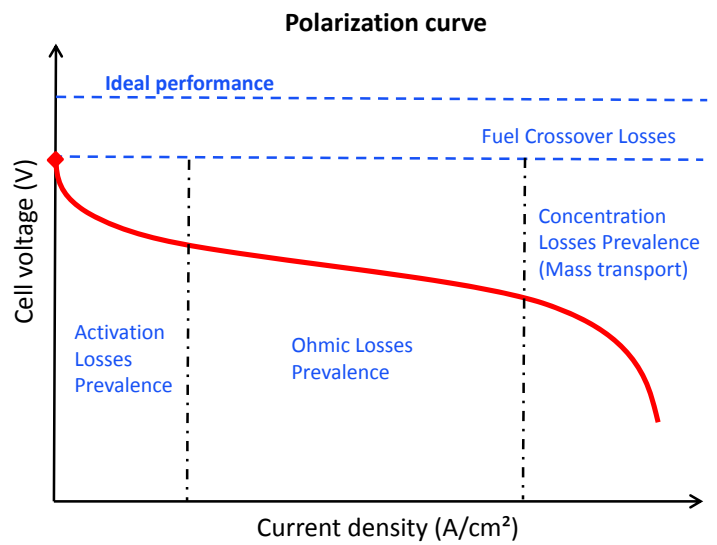

Figure 5: Visualizing losses: the polarization curve

Being able to model PEMFC behaviors and degradation processes can be very useful for applying PHM methodologies.

\section{State of the art of PHM regarding PEMFC}

Lots of research works have been published in the past years regarding PEMFC but none of them have ever adopted a PHM point of view. Consequently, in this section, we consider a certain amount of works by adopting this vision. Each layers is treated separately to emphasize their different characteristics. But we should fast give some vocabulary precisions. Indeed, in the PEMFC literature it is very common to find works entitled "diagnosis of ..." but very often from the PHM point of view the term diagnosis is misused. Instead of referring to diagnostics as fault detection and identification, they mostly focus on monitoring the current state of the stack or detect faults, but they rarely go further. With the same idea, works entitled "estimation of the lifespan of..." do not perform prognostics, even if they try to predict the evolution of some components, no remaining useful life is estimated. That's why one should keep in mind the definition of each layer previously introduced when trying to classify fuel cell works according to PHM statements.

The first step when using a PHM methodology is to choose the system studied. In this paper we will limit our work to the stack and its components, leaving aside ancillaries, but also to works realised after 2000 .

\subsection{Observation layers}

As PEM fuel cells are still in a process of development and all the internal processes are not fully understood, a great number of monitoring techniques have been applied. That's why, the observation layers are the most developed ones.

\subsubsection{Data Acquisition}

A large amount of techniques dedicated to data acquisition have been developed. Very often, home-made test benches are constructed to meet specific needs. Of course, usual sensors such as pressure sensors, thermocouples, flowmeter, ammeter, etc. are commonly used. They allows measuring common parameters as the cell or stack voltages and currents in static and dynamic modes [32], or pressure drops at the electrodes [33]. But more informative techniques are also employed due to the specific needs 
for stack or individual cells monitoring.

Electrochemical impedance spectroscopy (EIS) encounters a large success $[24,30,31]$. Indeed it enables characterizing electrode processes and complex interfaces by measuring the response of the system to the application of a periodic small amplitude AC signal [34]. This method gives relevant informations about both dynamic (through a large range of frequencies) and static behaviors. Nyquist plots can be constructed from these informations in the next PHM layers.

However more specific behavior-oriented means have been tested. Some are well described in [35] and [36]. Due to their great number, they are summarized in Table 2 but some are described here after:

- Gas chromatography to measure directly high levels of water saturation [37];

- Neutron imaging to localize condensed water [38];

- Current interrupt to measure cell resistances [39];

- Cyclic voltammetry to get informations about active areas of the electrodes [39];

- Linear sweep voltammetry to visualize hydrogen crossover [39];

- Transparent cells associated with a camera to record the evolution of liquid water content and locate flooded regions [40];

- Measurements of exit air humidity [41];

- Power compensated differential scanning calorimetry to measure specific heat of the membrane [42];

- Infrared camera to study the temperature distributions [42].

This list could be more exhaustive but it needn't to be longer to show the great diversity of tools that can be useful for fuel cell monitoring. What can be interesting to notice is that very few of these techniques meet all the requirements for transportable applications, namely, reliable, non-intrusive, non-damaging and easily implementable (in terms of time and money costs and volume) on-line technology.

\subsubsection{Data Processing}

To make raw data usable, a great variety of processing tools are available. Their choice is closely linked to the nature of gathered and to the condition assessment method used directly after. We can divide them in at least four categories.
Table 2: Summary of data acquisition techniques for PEMFC

\begin{tabular}{|l|l|}
\hline \multicolumn{1}{|c|}{ Means } & References \\
\hline EIS & {$[24,30,31]$} \\
\hline Gas or liquid chromatography & {$[37,43]$} \\
\hline Neutron imaging & {$[38,44]$} \\
\hline Current interrupt & {$[39,45,46]$} \\
\hline Cyclic voltammetry & {$[39,47]$} \\
\hline Linear sweep voltammetry & {$[39,47,48]$} \\
\hline High frequency resistance & {$[45,49]$} \\
\hline AC resistance & {$[45]$} \\
\hline MEMS sensors & {$[50,51]$} \\
\hline Transparent cells & {$[40,52,53]$} \\
\hline Segmented cells & {$[54,55,56]$} \\
\hline Measurements of exit air humidity & {$[41]$} \\
\hline Power compensated differential scan- \\
ning calorimetry & {$[42]$} \\
\hline Infrared imagery & {$[42,57,58]$} \\
\hline Chronoamperometry & {$[47,59,60,61]$} \\
\hline Chronopotentiometry & {$[61]$} \\
\hline Cathode discharge & {$[62]$} \\
\hline Micro-sensors for CO detection & {$[63,64]$} \\
\hline Chronocoulometry & {$[65]$} \\
\hline X-ray diffraction & {$[47]$} \\
\hline X-ray absorption fine structure spec- \\
troscopy & {$[66]$} \\
\hline Atomic absorption spectroscopy & {$[65,70,71]$} \\
\hline Mass spectroscopy & {$[67,68]$} \\
\hline Transmission electron microscopy & {$[60]$} \\
\hline Magnetic resonance imaging & {$[69]$} \\
\hline Scanning electron microscope and/or \\
Transmission electron microscope & {$[72]$} \\
\hline Acoustic emission & {$[67,5]$} \\
\hline
\end{tabular}

Feature extraction. This category gathers a great variety of methods. One of the most used is generating the polarization curve described earlier thanks to current density and voltage signals, as well as the Nyquist plot thanks to EIS measurements [24, 31, 73]. In [30], once the fitting realized, the authors are able to extract particular hyperparameters and follow their evolution during time. Various uses can be done from these plots, most of them are detailed in the condition assessment part. A quite different example is photo analysis, most often when experiments are done with a transparent fuel cell. Some specific behavioral characteristics such as start point of flooding can be identified [40].

Signal processing. These techniques provide informations about the signal in the frequency domain allowing to see some characteristics invisible in the time domain. They can be applied on different signals such as drop pressure, resistance variation or voltage. Two of them can be identified in the PEMFC literature, namely, Fast Fourier Transform (FFT) and Wavelet Transform (WT).

FFT is used in [74] in order to correlate the stack voltage evolution with the pressure drop across the electrodes in 
different operating conditions. The aim of the authors is then to find the dominant frequency of the cathode pressure drop and then to be able to predict the sudden stack voltage evolution indicating a flooding. But a drawback of such a method is that it is not adapted to non-stationary signals.

On the other side, WT is a multi-resolution analysis methods class that enables the examination of the signal and its local features under different scale and time localizations. It allowed to extract features which, once classified, are used to determine the fuel cell state of health. Some applications of WT can be found in $[32,75,76]$.

Model fitting. Very often, raw data show specific trends and can be used to determine empirical models. This can be achieved by using fitting procedures. In [77], a complex non-linear least square fitting is used to fit to the specific Nyquist plot obtained during CO-poisoning. In [30], approximations of the polarization curve, of real and imaginary parts of the impedance measurements by polynomial models are performed. The same idea of fitting to the Nyquist plot and polarization curve can be found in [24] but this time the analytical model (Randles model) is already known. We cite here only example of EIS data fitting but it is also performed with other kind of measurements (pressure drop, species concentration, etc.).

Statistical treatment. When a correlation seems to exist between the measured variables it could be interesting to use statistical treatments such as Principle Component Analysis (PCA) [72, 78, 79]. In [79], PCA aims at visualizing the different parameters, their variations and correlations, and then allows the authors to identify which ones mostly contribute to the stack behavior. This kind of post processing is also used in [72] for data discrimination between data coming from distinct origins for then categorizing them into different clusters. Here we can also quote data reduction [41] and data normalization [80] that are very helpful when a huge amount of data exist or when one wants to work with a small range of values.

\subsection{Modeling and analysis layers}

\subsubsection{Condition Assessment}

The condition assessment part is very often confused with the diagnostic part, once again detecting and localizing a system fault or its state of health belongs to condition assessment. On the other hand, diagnostic focus on fault identification. As previously said, modeling fuel cells behavior is quite difficult, making condition assessment complicated if only model-based. In simple phenomena studies, differential values between model data and measurements called residues can be generated and analyzed. The value of these residues enable assessing in which state the system is operating $[24,31,37,40]$ or in [81] described in 4.3. In [31], the residues are divided in different clusters thanks to one fuzzy clustering algorithm, each one corresponding to a different solicitation evolution. So, thanks to points location, deviations from the operating point can be detected. Fuzzy logic utilization can be found in [41]. Another method consists in using Artificial Neural Networks (ANN). In [32], ANN learns the correlation between voltage variations, pressure drop at the cathode and water conditions (normal, flooding or drying out) during the learning phase. Then during various simulations, it can indicate in which state the fuel cell is operating. Last example, for condition assessment, is the use of representation of characteristic parameters as in [24] where the 3D representation of the system ohmic, polarization and diffusion resistances once again helps determine the fuel cell state-of-health. A last tool, that is a starting point for diagnostic, is Bayesian networks [82].

\subsubsection{Diagnostic}

Directly following fault detection, diagnostic allows determining the failure causes. Even if significant works exist in that direction a lot of them are related to fault identification, which in this paper is called condition assessment. The causes of the failures are not always clearly identified, preventing these works to be classified as diagnostic in the PHM sense.

Great reviews summarizing diagnostic methods and the way they are used for PEMFC diagnostic can be found in $[28,83]$. On the one hand, [28] sums up model-based methodologies such as parameter identification methods [84, 85], observer-based model [86], parity space methods $[87,88]$, while on the other hand [83] presents non-model based ones namely Bayesian network [89, 90], some tools are common with fault detection.

To detail some examples, in [90] two Bayesian network structures are implemented, one with $\mathrm{K} 2$ algorithm the other with MCMC algorithm, and compared for fault identification. In [78], a different kind of method is tested. After applying PCA, a residual error effectiveness factor for each characteristic variable is attributed. From this and calculating a square prediction error, they manage to select possible causes of a voltage variation. In [91], the signatures of residues generated when a fault occurs are analyzed thanks to fuzzy logic rules and the fault cause can be identified. In this case, the only causes that can be identified are $\mathrm{H}_{2} \mathrm{O} / \mathrm{N}_{2}$ accumulation in the anode compartment or PEM drying but more rules could be added to identify more failure causes.

However, even if diagnostic helps identifying failure causes, it can only be performed after the fault occurs. Consequently it doesn't offer the possibility to anticipate failures and so prevents from acting on the system before it breaks down. One step further, enabling anticipation, in PHM set of activities is prognostics.

\subsubsection{Prognostics}

The prognostics layer is almost absent of PEMFC studies. As said in this part introduction, a few studies try to estimate the remaining lifespan of a specific component or a single cell. The main idea of these works 
is to determine in which part of the fuel cell life, the system is operating thanks to different aging tendencies and indicators empirically defined [92, 93]. It implies nevertheless to have a sufficient amount of data from multiple fuel cells. However, even if it does not looks like real prognostics, these papers can give starting points that once developed could lead to prognostics.

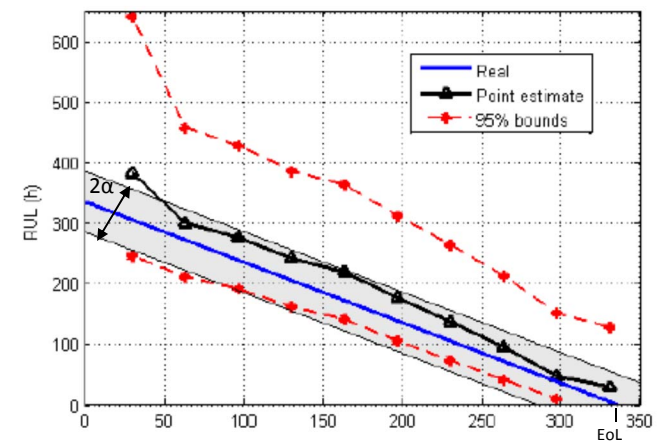

Figure 6: RUL prediction plot adapted from [94]

Only one paper in which a remaining useful life (RUL) is calculated has already been published until now [94]. It proposes a damage tracking and RUL prediction by using an unscented Kalman filter-based PHM scheme. A physics-based prognostic-oriented model is implemented in order to link the operating conditions to the degradation rate of the electro-chemical active surface area. The main idea is to use the size evolution of this area as an aging criterion and by linking it to output voltage, to perform RUL predictions. The end-of-life (EoL) of the fuel cell is assumed to occur when this area becomes to small to give an acceptable performance in terms of output voltage. The result given are evaluate with $\alpha$-performance metrics described in [95]. The metrics indicates whether the predicted estimates are within the specified limits around the actual EoL so that the prediction can be considered trustworthy. As we can see on Fig. 6 the predicted RUL is contained in the $2 \alpha$ zone meaning that its prognostics method shows good results. Yet, this prognostic is performed on a single cell (not a whole stack) and covers a short period of time $(300 \mathrm{~h})$. In an industrial perspective, research has to be reinforced to face those two limits.

\subsection{Decision Layers}

\subsubsection{Decision Support}

As regards decision support, there are not so much works dealing with automatic corrective actions. The American patent made by Bosco and Fronk [81] is the most complete paper dealing with this subject. Residues from pressure drop measurement across given hydrogen or oxygen flow fields are generated. These residues are compared to empirically defined threshold of unacceptability during the condition assessment and diagnosis phases. Then in case of fault detection, corrective actions are automatically launched in agreement with Fig. 7.

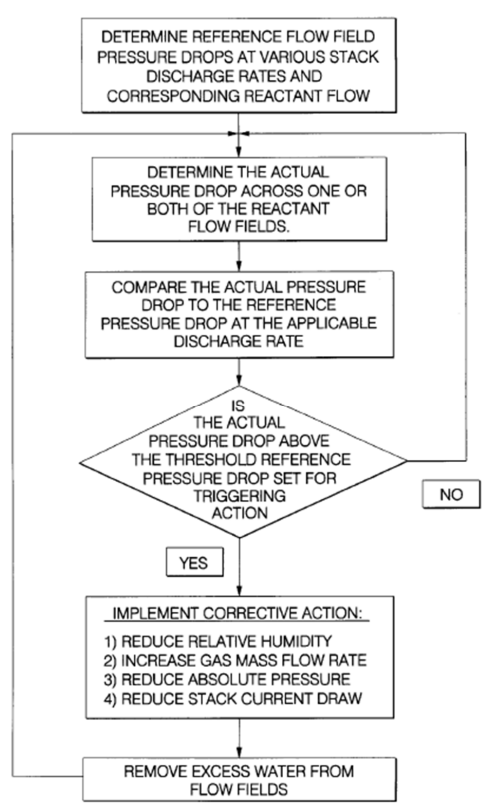

Figure 7: Automatic regulation of operating conditions [81]

\subsubsection{Human - Machine Interface}

No work dealing precisely with creating human - machine interface can be found in the literature. Indeed, work teams tend to develop homemade HMIs dedicated to their specific needs.

\subsection{Global overview}

The previous described layers are summarized in Fig. 8. The number of works on each layer correspond to the number of works cited in this state of the art. It aims at showing the proportion of works in each of them. As we can see, works' repartition on the different layers is very unequal. Let's now see in the next section what conclusions can be drawn from that and what challenges for PEMFC's PHM it highlights.

\section{Remaining Challenges and open issues}

As stated before, PEMFC community never adopted a PHM point of view regarding its work. That's why no paper dealing with CBM strategies for PEMFC or PHM vocabulary can be found. This brief state of the art reveals that all PHM layers are far from being complete and unevenly filled (Fig. 9). Moreover, one should keep in mind that PEM fuel cells, when used in an hybrid vehicle but also in much more smaller portable devices, are intended to be transportable. Thereby, some remaining challenging issues can be pointed out. There are synthesized in Fig. 10. 


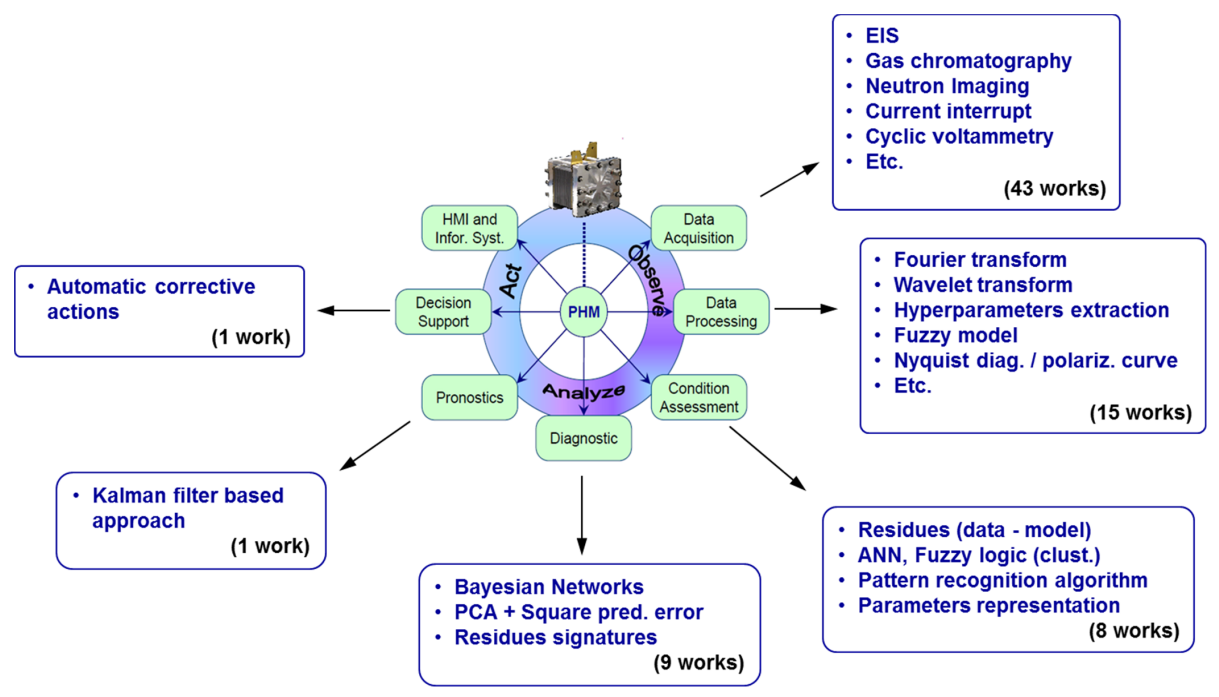

Figure 8: State of the art summary

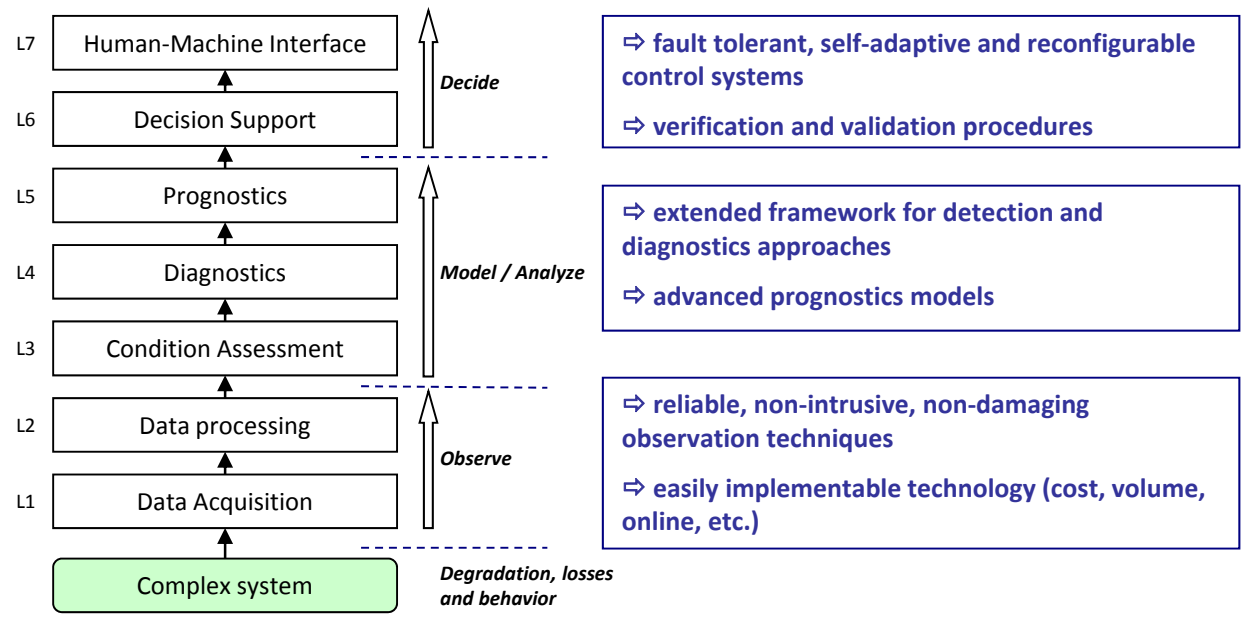

Figure 10: Remaining Challenges - Overview

\subsection{Observation}

Research on the development of data acquisition and processing techniques must be pursued so that improved observation strategies are reached. Indeed it should meet some requirements: being reliable, non-intrusive, and not inducing perturbations or even damages. They should consider the transportability of the measurement means and so being easily implementable in accordance with applicative constraints (cost, volume, rapid on line measurements, etc.). If we take a look at the data acquisition and processing techniques mentioned above, we can easily realize that almost all of them are laboratory techniques and are not appropriate for portable devices.

\subsection{Modeling and analysis}

Even if detection and diagnosis models exist, published works focus on specific points such as flooding, drying out or membrane degradation. Not all wearing mechanisms are taken into account within a single model. A lot of work has been done aiming at determining the state-of-health of the fuel cell, but very few focus on fault identification. It is a good thing to know that a fault has occurred, but it is even better to know why. So diagnostic has to be more developed. As far as prognostics is concerned, one can point out that a complete model taking into account the fuel cell behavior, the degradation processes involved, as well as environmental and operating conditions is still missing. Even if data-driven prognostics can be performed, solid basis have to be found to ensure prognostics developments.

\subsection{Decision}

One should not forget that the decision support layer is almost empty too. Fault-tolerant, self-adaptive and re- 


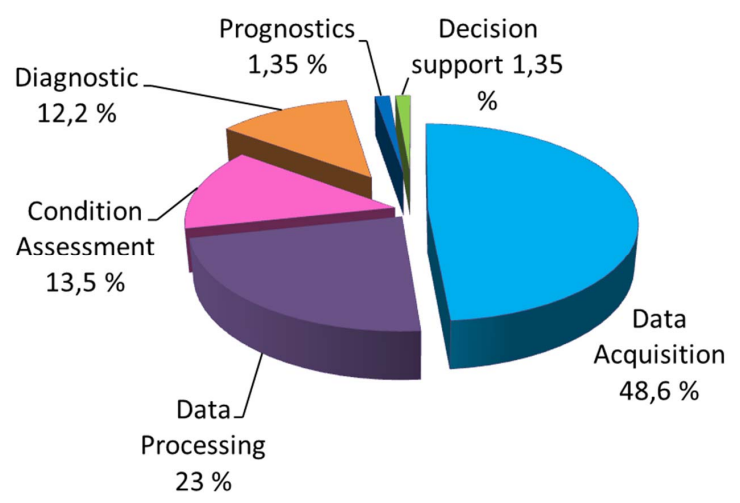

Figure 9: Cited 63 works repartition (some are used on several layers)

configurable control algorithms have to be developed so that the mission can be achieved in the best conditions. Also verification and validation of modeling techniques is an ill-problem, an ongoing issue for PHM community.

\subsection{Facing the challenges}

To face the afore-mentioned issues, the amount of experimental data is crucial. Indeed, to develop complete models for behavior, aging and degradations a great quantity of data in needed. Moreover to ensure the generality and the transferability of the models data coming from various mission profiles and different operating conditions should be gathered. Considering the long periods of time required to obtain complete results from experiments on PEMFC stacks, one way to achieve this goal could be the creation of international data bases as it is commonly done in other communities. An example is the PHM community with the NASA data base [96], in which a large amount of data is available for worldwide prognostic research.

As lots of PHM methodologies are already existing and can be adapted from one field to another (examples of application section 2.3), the major work, at least for diagnostic and prognostics, relies on finding aging models, trends or indicators that would help anticipating failures and determining the remaining useful life.

\section{Conclusion}

This paper proposes a solution to extend PEMFC lifespan, namely, Prognostics and Health Management. Once PHM and its 7 layers are presented, a state of the art classifying PEMFC works on PHM layers is drawn. Directly following this classification, remaining challenges and perspective of work are highlighted.

Considering benefits that can be expected, FC community has a growing interest in PHM technology. PHM approaches aim at transforming raw monitoring data into relevant information and behavior models (including the degradation) of the system. They take as inputs the current monitoring data and return as outputs predictions or trends about the health state of the system.

This state of the art allows positioning a certain number of works in the PHM scheme and showing how these works are mostly gathered in the "observe" layers. It also enables pointing out the remaining challenges and main directions for work that can be adopted regarding PHM for PEMFC. One can easily note that the greatest challenge to tackle is the one of prognostics.

\section{References}

[1] M. Pecht, R. Jaai, A prognostics and health management roadmap for information and electronics-rich systems, Microelectronics Reliability 50 (3) (2010) 317-323.

[2] M. Lebold, K. Reichard, D. Boylan, Utilizing dcom in an open system architecture framework for machinery monitoring and diagnostics, in: Aerospace Conference, 2003. Proceedings. 2003 IEEE, Vol. 3, 2003, pp. 1227-1236.

[3] R. Gouriveau, K. Medjaher, Chapter 2 : Industrial prognostic - an overview, in: C. B. J. Andrews, L. Jackson (Eds.), Maintenance Modelling and Applications, ISBN : 978-82-515-0316-7, Det Norske Veritas (DNV), 2011, pp. 10-30.

[4] ISO13381-1, Condition monitoring and diagnostics of machines - prognostics - Part1: General guidelines, International Standard, ISO, 2004.

[5] J. Sikorska, M. Hodkiewicz, L. Ma, Prognostic modelling options for remaining useful life estimation by industry, Mechanical Systems and Signal Processing 25 (5) (2011) 1803 - 1836.

[6] A.-K.-S. Jardine, D. Lin, D. Banjevic, A review on machinery diagnostics and prognostics implementing condition-based maintenance, Mech. Systems and Sig. Processing 20 (2006) 1483-1510.

[7] G. Vachtsevanos, F. L. Lewis, M. Roeme, A. Hess, B. Wug, Intelligent Fault Diagnostic and Prognosis for Engineering Systems, John Wiley \& Sons, 2006.

[8] A. Heng, S. Zhang, A. C. Tan, J. Mathew, Rotating machinery prognostics: State of the art, challenges and opportunities, Mechanical Systems and Signal Processing 23 (3) (2009) 724 739 .

[9] M. Gaperin, ani Jurii, P. Bokoski, J. Viintin, Model-based prognostics of gear health using stochastic dynamical models, Mechanical Systems and Signal Processing 25 (2) (2011) $537-548$.

[10] F. Zhao, Z. Tian, Y. Zeng, A stochastic collocation approach for efficient integrated gear health prognosis, Mechanical Systems and Signal Processing (0) (2013) -.

[11] J.-H. Zhou, C. K. Pang, Z.-W. Zhong, F. L. Lewis, Tool wear monitoring using acoustic emissions by dominant-feature identification, IEEE Tr. on Instrument. and Measurement 60 (2011) $547-559$

[12] J. Dai, D. Das, M. Ohadi, M. Pecht, Reliability risk mitigation of free air cooling through prognostics and health management, Applied Energy 111 (0) (2013) $104-112$.

[13] J. Zhang, J. Lee, A review on prognostics and health monitoring of li-ion battery, Journal of Power Sources 196 (15) (2011) 6007 -6014 .

[14] C. Robin, M. Gerard, A. A. Franco, P. Schott, Multi-scale coupling between two dynamical models for $\{$ PEMFC $\}$ aging prediction, International Journal of Hydrogen Energy 38 (11) (2013) 4675 - 4688 .

[15] W. Schmittinger, A. Vahidi, A review of the main parameters influencing long-term performance and durability of $\{$ PEM $\}$ fuel cells, Journal of Power Sources 180 (1) (2008) 1 - 14

[16] S. D. Knights, K. M. Colbow, J. St-Pierre, D. P. Wilkinson, Aging mechanisms and lifetime of $\{\mathrm{PEFC}\}$ and $\{\mathrm{DMFC}\}$, Journal of Power Sources 127 (12) (2004) $127-134$.

[17] N. Yousfi-Steiner, P. Moçotéguy, D. Candusso, D. Hissel, A. Hernandez, A. Aslanides, A review on $\{$ PEM $\}$ voltage degradation associated with water management: Impacts, influent 
factors and characterization, Journal of Power Sources 183 (1) (2008) $260-274$.

[18] N. Yousfi-Steiner, P. Moçotéguy, D. Candusso, D. Hissel, A review on polymer electrolyte membrane fuel cell catalyst degradation and starvation issues: Causes, consequences and diagnostic for mitigation, Journal of Power Sources 194 (1) (2009) $130-145$

[19] J. Wu, X. Z. Yuan, J. J. Martin, H. Wang, J. Zhang, J. Shen, S. Wu, W. Merida, A review of $\{$ PEM $\}$ fuel cell durability: Degradation mechanisms and mitigation strategies, Journal of Power Sources 184 (1) (2008) $104-119$.

[20] Z.-D. Zhong, X.-J. Zhu, G.-Y. Cao, J.-H. Shi, A hybrid multivariable experimental model for a $\{$ PEMFC $\}$, Journal of Power Sources 164 (2) (2007) $746-751$.

[21] S. Jemei, D. Hissel, M.-C. Péra, J.-M. Kauffmann, A new modeling approach of embedded fuel-cell power generators based on artificial neural network, Industrial Electronics, IEEE Transactions on 55 (1) (2008) 437-447.

[22] Y. Vural, D. B. Ingham, M. Pourkashanian, Performance prediction of a proton exchange membrane fuel cell using the $\{$ ANFIS model, International Journal of Hydrogen Energy 34 (22) (2009) $9181-9187$

[23] X. Li, G. yi Cao, X. jian Zhu, Modeling and control of $\{$ PEMFC $\}$ based on least squares support vector machines, Energy Conversion and Management 47 (78) (2006) 1032 - 1050.

24] N. Fouquet, C. Doulet, C. Nouillant, G. Dauphin-Tanguy, B. Ould-Bouamama, Model based pem fuel cell state-of-health monitoring via ac impedance measurements, Journal of Power Sources 159 (2) (2006) 905 - 913.

[25] S. Asghari, A. Mokmeli, M. Samavati, Study of $\{$ PEM $\}$ fuel cell performance by electrochemical impedance spectroscopy, International Journal of Hydrogen Energy 35 (17) (2010) 9283 9290.

[26] A. Bykolu, Review of proton exchange membrane fuel cell models, International Journal of Hydrogen Energy 30 (11) (2005) $1181-1212$

[27] M. Becherif, A. Saadi, D. Hissel, A. Aboubou, M. Ayad, Summary of the pem fuel cell modeling.

[28] R. Petrone, Z. Zheng, D. Hissel, M. Péra, C. Pianese, M. Sorrentino, M. Becherif, N. Yousfi-Steiner, A review on model-based diagnosis methodologies for \{PEMFCs\}, International Journal of Hydrogen Energy (0) (2013) -. doi:10.1016/j.ijhydene.2013.03.106.

[29] D. Hissel, C. Turpin, S. Astier, L. Boulon, M.-C. Péra, S. Jemei, et al., A review on existing modeling methodologies for pem fuel cell systems, Fundamentals and developments of fuel cells conference.

[30] R. Onanena, L. Oukhellou, D. Candusso, F. Harel, D. Hissel, P. Aknin, Fuel cells static and dynamic characterizations as tools for the estimation of their ageing time, International Journal of Hydrogen Energy 36 (2) (2011) 1730 - 1739.

[31] D. Hissel, D. Candusso, F. Harel, Fuzzy-clustering durability diagnosis of polymer electrolyte fuel cells dedicated to transportation applications, Vehicular Technology, IEEE Transactions on 56 (5) (2007) 2414-2420.

[32] N. Y. Steiner, D. Hissel, P. Moçotéguy, D. Candusso, Diagnosis of polymer electrolyte fuel cells failure modes (flooding and drying out) by neural networks modeling, International Journal of Hydrogen Energy 36 (4) (2011) 3067 - 3075.

[33] W. He, G. Lin, T. Van Nguyen, Diagnostic tool to detect electrode flooding in proton-exchange-membrane fuel cells, AIChE Journal 49 (12) (2003) 3221-3228.

[34] A. Lasia, Electrochemical Impedance Spectroscopy and its Applications, Vol. 32, Springer US, 1999.

[35] J. Wu, X. Z. Yuan, H. Wang, M. Blanco, J. J. Martin, J. Zhang, Diagnostic tools in $\{\mathrm{PEM}\}$ fuel cell research: Part i electrochemical techniques, International Journal of Hydrogen Energy 33 (6) (2008) $1735-1746$

[36] J. Wu, X. Z. Yuan, H. Wang, M. Blanco, J. J. Martin, J. Zhang, Diagnostic tools in $\{$ PEM $\}$ fuel cell research: Part ii: Physical/chemical methods, International Journal of Hydrogen En- ergy 33 (6) (2008) $1747-1757$

[37] M. Mench, Q. Dong, C. Wang, In situ water distribution measurements in a polymer electrolyte fuel cell, Journal of Power Sources 124 (1) (2003) $90-98$.

[38] R. Satija, D. Jacobson, M. Arif, S. Werner, In situ neutron imaging technique for evaluation of water management systems in operating pem fuel cells, Journal of Power Sources 129 (2) (2004) $238-245$

[39] S. Wasterlain, D. Candusso, F. Harel, D. Hissel, X. Franois, Development of new test instruments and protocols for the diagnostic of fuel cell stacks, Journal of Power Sources 196 (12) (2011) $5325-5333$

[40] K. Tuber, D. Pócza, C. Hebling, Visualization of water buildup in the cathode of a transparent pem fuel cell, Journal of Power Sources 124 (2) (2003) $403-414$.

[41] Fuzzy logic-based state-of-health determination of pem fuel cells, Procs.EVS 18.

[42] L. Martins, J. Gardolinski, J. Vargas, J. Ordonez, S. Amico, M. Forte, The experimental validation of a simplified pemfc simulation model for design and optimization purposes, Applied Thermal Engineering 29 (1415) (2009) 3036 - 3048.

[43] T. Araki, H. Koori, T. Taniuchi, K. Onda, Simulation of the current density distribution for a $\{$ PEMFC $\}$ by using measured electrochemical and physical properties of the membrane, Journal of Power Sources 152 (0) (2005) $60-66$

44] J. Park, X. Li, D. Tran, T. Abdel-Baset, D. Hussey, D. Jacobson, M. Arif, Neutron imaging investigation of liquid water distribution in and the performance of a $\{\mathrm{PEM}\}$ fuel cell, International Journal of Hydrogen Energy 33 (13) (2008) 3373 3384 .

[45] K. Cooper, M. Smith, Electrical test methods for on-line fuel cell ohmic resistance measurement, Journal of Power Sources 160 (2) (2006) $1088-1095$.

[46] F. Jaouen, G. Lindbergh, Transient techniques for investigating mass-transport limitations in gas diffusion electrodes: I. modeling the pefc cathode, Journal of The Electrochemical Society 150 (12) (2003) A1699-A1710.

[47] J. Moreira, P. del Angel, A. Ocampo, P. Sebastin, J. Montoya, R. Castellanos, Synthesis, characterization and application of a $\mathrm{pd} /$ vulcan and pd/c catalyst in a $\{\mathrm{PEM}\}$ fuel cell, International Journal of Hydrogen Energy 29 (9) (2004) 915 - 920.

48] M. Inaba, T. Kinumoto, M. Kiriake, R. Umebayashi, A. Tasaka, Z. Ogumi, Gas crossover and membrane degradation in polymer electrolyte fuel cells, Electrochimica Acta 51 (26) (2006) 5746 5753

[49] M. Sankir, Y. S. Kim, B. S. Pivovar, J. E. McGrath, Proton exchange membrane for $\{\mathrm{DMFC}\}$ and h2/air fuel cells: Synthesis and characterization of partially fluorinated disulfonated poly(arylene ether benzonitrile) copolymers, Journal of Membrane Science 299 (12) (2007) 8 - 18

[50] C.-Y. Lee, Y.-M. Lee, In-situ diagnosis of local fuel cell performance using novel micro sensors, International Journal of Hydrogen Energy 37 (5) (2012) 4448 - 4456.

[51] A. Su, Y. Ferng, W. Chen, C. Cheng, F. Weng, C. Lee, Investigating the transport characteristics and cell performance for a micro $\{$ PEMFC $\}$ through the micro sensors and $\{\mathrm{CFD}\}$ simulations, International Journal of Hydrogen Energy 37 (15) (2012) $11321-11333$.

[52] X. Liu, H. Guo, C. Ma, Water flooding and two-phase flow in cathode channels of proton exchange membrane fuel cells, Journal of Power Sources 156 (2) (2006) $267-280$.

[53] S. Ge, C.-Y. Wang, In Situ Imaging of Liquid Water and Ice Formation in an Operating PEFC during Cold Start, Electrochemical and Solid-State Letters 9 (11) (2006) A499-A503.

[54] P. Ghosh, T. Wster, H. Dohle, N. Kimiaie, J. Mergel, D. Stolten, In situ approach for current distribution measurement in fuel cells, Journal of Power Sources 154 (1) (2006) 184 - 191.

[55] A. Hakenjos, C. Hebling, Spatially resolved measurement of $\{$ PEM $\}$ fuel cells, Journal of Power Sources 145 (2) (2005) 307 $-311$.

[56] X.-G. Yang, N. Burke, C.-Y. Wang, K. Tajiri, K. Shinohara, Si- 
multaneous measurements of species and current distributions in a pefc under low-humidity operation, Journal of The Electrochemical Society 152 (4) (2005) A759-A766.

[57] M. Wang, H. Guo, C. Ma, Temperature distribution on the \{MEA $\}$ surface of a $\{$ PEMFC $\}$ with serpentine channel flow bed, Journal of Power Sources 157 (1) (2006) 181 - 187.

[58] Nasas jet propulsion laboratory pasadena, thermal imaging for diagnosing fuel cells, http://www.nasatech.com/briefs/nov01/npo21177.html,.

[59] D. Gerteisen, T. Heilmann, C. Ziegler, Modeling the phenomena of dehydration and flooding of a polymer electrolyte membrane fuel cell, Journal of Power Sources 187 (1) (2009) 165 - 181.

[60] H. Xu, X. Hou, Synergistic effect of modified pt/c electrocatalysts on the performance of $\{\mathrm{PEM}\}$ fuel cells, International Journal of Hydrogen Energy 32 (17) (2007) 4397 - 4401.

[61] R. M. Rao, R. Rengaswamy, A distributed dynamic model for chronoamperometry, chronopotentiometry and gas starvation studies in $\{\mathrm{PEM}\}$ fuel cell cathode, Chemical Engineering Science 61 (22) (2006) $7393-7409$.

[62] J. Stumper, M. Lhr, S. Hamada, Diagnostic tools for liquid water in $\{$ PEM $\}$ fuel cells, Journal of Power Sources 143 (12) (2005) $150-157$.

[63] C. Pijolat, G. Tournier, J. Viricelle, Detection of $\{\mathrm{CO}\}$ in h2rich gases with a samarium doped ceria (sdc) sensor for fuel cell applications, Sensors and Actuators B: Chemical 141 (1) (2009) $7-12$.

[64] C. G. Reddy, P. K. Dutta, S. A. Akbar, Detection of $\{\mathrm{CO}\}$ in a reducing, hydrous environment using cubr as electrolyte, Sensors and Actuators B: Chemical 92 (3) (2003) 351 - 355.

[65] J. Yu, T. Matsuura, Y. Yoshikawa, M. Nazrul Islam, M. Hori, Lifetime behavior of a pem fuel cell with low humidification of feed stream, Phys. Chem. Chem. Phys. 7 (2005) 373-378.

[66] A. Witkowska, E. Principi, A. D. Cicco, S. Dsoke, R. Marassi, L. Olivi, M. Centazzo, V. R. Albertini, Temperature and potential-dependent structural changes in a pt cathode electrocatalyst viewed by in situ $\{\mathrm{XAFS}$, Journal of Non-Crystalline Solids 354 (3539) (2008) 4227 - 4232.

[67] H.-S. Oh, J.-G. Oh, S. Haam, K. Arunabha, B. Roh, I. Hwang, H. Kim, On-line mass spectrometry study of carbon corrosion in polymer electrolyte membrane fuel cells, Electrochemistry Communications 10 (7) (2008) 1048 - 1051.

[68] K. H. Lim, H.-S. Oh, H. Kim, Use of a carbon nanocage as a catalyst support in polymer electrolyte membrane fuel cells, Electrochemistry Communications 11 (6) (2009) 1131 - 1134.

[69] S. Tsushima, K. Teranishi, S. Hirai, Magnetic resonance imaging of the water distribution within a polymer electrolyte membrane in fuel cells, Electrochemical and Solid-State Letters 7 (9) (2004) A269-A272.

[70] V. Kamavaram, V. Veedu, A. Kannan, Synthesis and characterization of platinum nanoparticles on in situ grown carbon nanotubes based carbon paper for proton exchange membrane fuel cell cathode, Journal of Power Sources 188 (1) (2009) 51 56.

[71] D. Liu, S. Case, Durability study of proton exchange membrane fuel cells under dynamic testing conditions with cyclic current profile, Journal of Power Sources 162 (1) (2006) 521 - 531.

[72] B. Legros, P.-X. Thivel, Y. Bultel, M. Boinet, R. Nogueira, Acoustic emission: Towards a real-time diagnosis technique for proton exchange membrane fuel cell operation, Journal of Power Sources 195 (24) (2010) 8124 - 8133.

[73] W. Merida, D. Harrington, J. L. Canut, G. McLean, Characterisation of proton exchange membrane fuel cell (pemfc) failures via electrochemical impedance spectroscopy, Journal of Power Sources 161 (1) (2006) $264-274$.

[74] J. Chen, B. Zhou, Diagnosis of $\{$ PEM $\}$ fuel cell stack dynamic behaviors, Journal of Power Sources 177 (1) (2008) 83 - 95.

[75] M. Ibrahim, S. Jemei, W. G., H. D., Wavelet- neural network approach for on-line prediction of time series: Application on power demand signal in a fuel cell hybrid vehicle, in: Fundamentals and Development of Fuel Cells (FDFC) 2013, 2013.

[76] U. Antoni, N. Y. Steiner, B. Ludwig, Signal-based pattern recognition approach for pem fuel cell diagnostics, in: Fundamentals and Development of Fuel Cells (FDFC) 2013, 2013.

[77] N. Wagner, M. Schulze, Change of electrochemical impedance spectra during $\{\mathrm{CO}\}$ poisoning of the pt and ptru anodes in a membrane fuel cell (pefc), Electrochimica Acta 48 (2526) (2003) $3899-3907$.

[78] J. Hua, J. Li, M. Ouyang, L. Lu, L. Xu, Proton exchange membrane fuel cell system diagnosis based on the multivariate statistical method, International Journal of Hydrogen Energy 36 (16) (2011) $9896-9905$

[79] L. Placca, R. Kouta, D. Candusso, J.-F. Blachot, W. Charon, Analysis of $\{\mathrm{PEM}\}$ fuel cell experimental data using principal component analysis and multi linear regression, International Journal of Hydrogen Energy 35 (10) (2010) 4582 - 4591.

[80] N. Yousfi Steiner, D. Hissel, P. Moçotéguy, D. Candusso, Non intrusive diagnosis of polymer electrolyte fuel cells by wavelet packet transform, International Journal of Hydrogen Energy 36 (1) (2011) $740-746$.

[81] A. Dipierno Bosco, M. H. Fronk, Fuel cell flooding detection and correction, US Patent (6103409)

[82] S. Wasterlain, D. Candusso, F. Harel, X. Franois, D. Hissel, Diagnosis of a fuel cell stack using electrochemical impedance spectroscopy and bayesian networks, in: Vehicle Power and Propulsion Conference (VPPC), 2010 IEEE, 2010, pp. 1-6.

[83] Z. Zheng, R. Petrone, M. Péra, D. Hissel, M. Becherif, C. Pianese, N. Y. Steiner, M. Sorrentino, A review on non-model based diagnosis methodologies for $\{\mathrm{PEM}\}$ fuel cell stacks and systems, International Journal of Hydrogen Energy 38 (21) (2013) $8914-8926$

[84] A. Zeller, O. Rallieres, J. Regnier, C. Turpin, Diagnosis of a hydrogen/air fuel cell by a statistical model-based method, in: Vehicle Power and Propulsion Conference (VPPC), 2010 IEEE, 2010, pp. 1-6.

[85] A. Hernandez, D. Hissel, R. Outbib, Modeling and fault diagnosis of a polymer electrolyte fuel cell using electrical equivalent analysis, Energy Conversion, IEEE Transactions on 25 (1) (2010) 148-160.

[86] S. De Lira, V. Puig, J. Quevedo, Robust lpv model-based sensor fault diagnosis and estimation for a pem fuel cell system, in: Control and Fault-Tolerant Systems (SysTol), 2010 Conference on, 2010, pp. 819-824.

87] Q. Yang, A. Aitouche, B. Bouamama, Fault detection and isolation of pem fuel cell system by analytical redundancy, in: Control Automation (MED), 2010 18th Mediterranean Conference on, 2010, pp. 1371-1376.

[88] M. Buchholz, M. Eswein, V. Krebs, Modelling pem fuel cell stacks for fdi using linear subspace identification, in: Control Applications, 2008. CCA 2008. IEEE International Conference on, 2008, pp. 341-346.

[89] S. Wasterlain, D. Candusso, F. Harel, X. Franois, D. Hissel, Diagnosis of a fuel cell stack using electrochemical impedance spectroscopy and bayesian networks, in: Vehicle Power and Propulsion Conference (VPPC), 2010 IEEE, 2010, pp. 1-6.

[90] L. A. M. Riascos, M. G. Simoes, P. E. Miyagi, A bayesian network fault diagnostic system for proton exchange membrane fuel cells, Journal of Power Sources 165 (1) (2007) 267 - 278.

[91] D. Hissel, M. Pra, J. Kauffmann, Diagnosis of automotive fuel cell power generators, Journal of Power Sources 128 (2) (2004) $239-246$.

[92] J. hyung Lee, J.-H. Lee, W. Choi, K.-W. Park, H.-Y. Sun, J.-H. Oh, Development of a method to estimate the lifespan of proton exchange membrane fuel cell using electrochemical impedance spectroscopy, Journal of Power Sources 195 (18) (2010) 6001 6007.

[93] E. Laffly, M.-C. Péra, D. Hissel, Polymer electrolyte membrane fuel cell modelling and parameters estimation for ageing consideration, in: Industrial Electronics, 2007. ISIE 2007. IEEE International Symposium on, 2007, pp. 180-185.

[94] X. Zhang, P. Pisu, An unscented kalman filter based approach for the health-monitoring and prognostics of a polymer electrolyte membrane fuel cell, in: Proceedings of the annual con- 
ference of the prognostics and health management society, 2012.

[95] A. Saxena, J. Celaya, B. Saha, S. Saha, K. Goebel, On applying the prognostic performance metrics, in: Proceedings of the annual conference of the prognostics and health management society, 2009

[96] NASA, Prognostics center of excellence (2013).

URL http://ti.arc.nasa.gov/tech/dash/pcoe/prognosticdata-repository/ 